\title{
Pengaruh Struktur Modal dan Likuiditas Terhadap Profitabilitas Perusahaan Otomotif di Indonesia pada PT Astra Internasional Tbk
}

\author{
Ermaini, Ade Irma Suryani, Endah Tri Kurniasih, Arman Syafa`at, Rian Dani \\ Fakultas Ekonomi dan Bisnis Universitas Muhammadiyah Jambi \\ Correspondence email : ermaini73@gmail.com
}

\begin{abstract}
PT. Astra Internasional Tbk, is a multinational company listed on the Indonesia Stock Exchange from 1990 until now and incorporated in the automotive industry. The covid-19 pandemic made the automotive industry both in Indonesia and in the world weakened by the decline in sales of almost all automotive companies. The focus of this research is to analyze the capital structure of the Debt to Equity Ratio (DER) and liquidity ratio, namely the Cash Ratio (CR) ratio of automotive companies and their effect on profitability, namely the Return on Equity Ratio (ROE) for the period 2016 to 2020 by using secondary data sourced from annual reports published by the company. The results of the study found that the performance of the company's capital structure, liquidity and profitability during 2016 to 2019 had a positive trend and in 2020 decreased as a result of the Covid-19 pandemic outbreak. Furthermore, the ratio of capital structure and liquidity has a positive influence with a significant rate of $<5 \%$.
\end{abstract}

Keywords: Liquidity, Profitability, and Capital Structure

\section{Pendahuluan}

Industri otomotif menjadi industri utama dalam menggerakan roda perekonomian suatu negara. Banyaknya perusahaan yang bergantung pada industri ini dapat dilihat dari penyedia terhadap bahan baku hingga pada pasca penjualan. Sehingga tidak diherankan jika pemerintah menaruh perhatian khusus terhadap pergerakan dari industri otomotif tersebut baik di negara Indonesia maupun negara lainnya. Pandemi Covid 19 yang terjadi di akhir tahun 2019 menjadi suatu bencana bagi industri otomotif tersebut. Tingkat penjualan industri otomotif di Asia Tenggara pada tahun 2020 mengalami penurunan sebesar 29\%. Bagitu pula disebutkan oleh Gaikindo (Gabungan Industri Kendaraan Bermotor Indonesia). PT. Astra Internasional Tbk merupakan perusahaan yang tergabung dalam industri Otomotif dengan kapitasi pasar paling tinggi atau besar di Bursa Efek Indonesia (BEI) jika dibandingkan dengan perusahaanperusahaan lainnya yang ada di industri otomotif dengan nilai sebesar Rp.190,68 Trilliun juga mengalami dampak penurunan penjualan. Berdasarkan laporan tahunan pada tahun 2020 pendapat bersih yang berhasil didapatkan oleh PT. Astra Internasional Tbk (ASII) turun sebesar 26,18\% jika dibandingkan dengan pendapatan pada tahun 2019. Penurunan terhadap pendapatan akan berakibat pada penurunan kinerja keuangan lainnya, sehingga diperlukan analisis terhadap laporan keuangan. Menurut Wiarta (2020) laporan keuangan itu sendiri merupakan penilain terhadap kinerja keuangan dari perusahaan tersebut dalam bidang permodalan, operasional, likuiditas dalam menghasilkan laba pada kurun waktu tertentu.

Struktur Modal dan likuiditas perusahaan akan berubah sesuai dengan perubahan tingkat pendapatan dari perusahaan yang terlihat dari seberapa besar profitabilitas yang dapat dihasilkan oleh perusahaan tersebut. Untuk itu diperlukan analisis terhadap struktur modal dari PT. Astra Internasional Tbk yaitu dengan analisis DER dan juga Likuiditasnya yaitu rasio CR dan juga profitabilitas dari perusahaan yaitu rasio ROE. Tujuan penelitian ini adalah untuk mengetahui pengaruh struktur modal dan likuiditas terhadap profitabilitas perusahaan pada PT. Astra Internasional Tbk.

\section{Metode}

Penelitian ini dilakukan oleh peneliti dengan cara analisis terhadap laporan tahunan yang dipublikasikan oleh perusahaan. Adapun metode penelitiannya yaitu dengan melakukan analisis deskriptif kuantitatif. Metode deskriptif adalah metode penelitian yang sering digunakan dalam ilmu sosial dengan tujuan untuk membuat gambaran mengenai situasi atau kejadian, sedangkan analisis kuantitatif merupakan metode analisis yang melakukan perhitungan terhadap data-data yang bersifat pembuktian dari masalah (Daniel, 2020). Dari uraian diatas, dapat disimpulkan bahwa metode deskriptif kuantitatif merupakan sebuah metode penelitan yang mengambarkan dan menjelaskan data melalui perhitungan angka-angka. Data penelitian yang digunakan oleh peneliti yaitu data sekunder yang diperoleh dari laporan tahunan PT. Astra Internasional Tbk, Periode 2016 sampai dengan 2020 yang diperoleh melalui halaman website perusahaan dan juga melalui unduhan pada website Bursa Efek Indonesia. 
Ermaini et al., Pengaruh Struktur Modal dan Likuiditas Terhadap Profitabilitas Perusahaan Otomotif di Indonesia pada PT Astra Internasional Tbk

\section{Hasil}

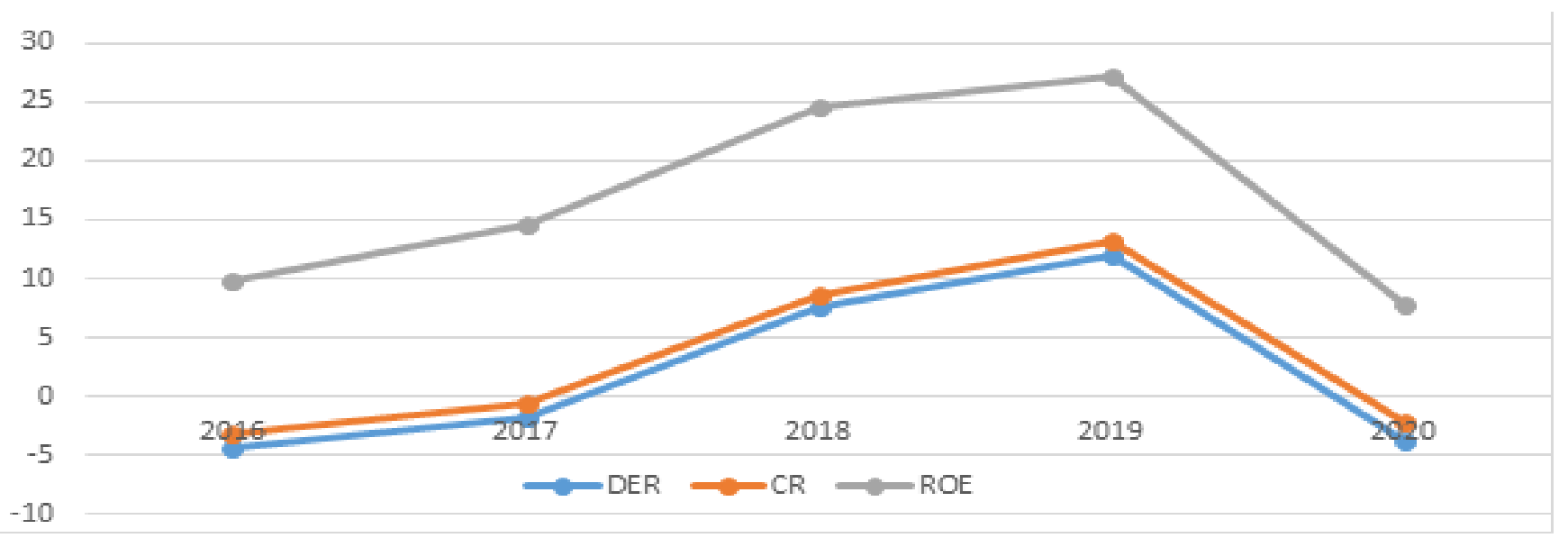

Sumber: olahan data

\section{Gambar 1}

\section{Perkembangan Nilai Rasio PT. Astra Internasional Tbk Periode 2016 - 2020}

Gambar 1 dapat diketahui bahwa rasio-rasio keuangan baik likuiditas, struktur modal dan juga profitabilitas dari perusahaan mengalami tren yang selalu sama antara satu dengan lainnya. Pada tahun 2016 sampai dengan 2019 tren dari grafik yaitu meningkat, dan pada tahun 2020 dengan adanya wabah pandemi covid 19 mengakibatkan seluruh kinerja keuangan memiliki trend negatif yaitu mengalami penurunan dari tahun sebelumnya. Baik rasio DER, CR maupun ROE PT. Astra Internasional mengalami peningkatan besar pada tahun 2017 sampai dengan 2018 yang ditandai dengan garis grafik yang memiliki kemiringan yang tinggi dan melandai kembali pada tahun 2019 dikarenakan pada akhir tahun wabah pandemi mulai terjadi di negara China. Analisis regresi linier sederhana digunakan untuk mengetahui apakah terdapat hubungan yang erat atau kuat antara variabel bebas dan variabel terikat. Untuk itulah dilakukan analisis regresi linier sederhana terhadap rasio struktur modal (DER) dan likuiditas (CR) terhadap Profitabilitas (ROE).

Tabel 1

Koefisien

\begin{tabular}{|c|c|c|c|c|c|c|}
\hline & \multirow[b]{2}{*}{ Model } & \multicolumn{2}{|c|}{ Unstandardized Coefficients } & \multirow{2}{*}{$\frac{\text { Standardized Coefficients }}{\text { Beta }}$} & \multirow[b]{2}{*}{$\mathrm{t}$} & \multirow[b]{2}{*}{ Sig. } \\
\hline & & $\mathrm{B}$ & Std. Error & & & \\
\hline \multirow[t]{3}{*}{1} & (Constant) & 29,313 & 3,892 & & 7,532 &, 017 \\
\hline & DER &, 096 &, 063 &, 305 & 1,522 & ,268 \\
\hline & $\mathrm{CR}$ & $-12,616$ & 3,044 &,- 831 & $-4,144$ &, 054 \\
\hline
\end{tabular}

Sumber: olahan data

Tabel 1 didapatkan persamaan yaitu nilai konstanta sebesar 29,313 yang berarti bahwa jika rasio struktur modal yaitu DER dan rasio likuiditas yaitu nilai dari rasio CR sama dengan Nol, maka rasio profitabilitas atau ROE akan tetap tumbuh sebesar 29,313. Selanjutnya berdasarkan dari fungsi persamaan diatas, maka diperoleh persamaan yaitu $\mathrm{Y}=29,313+0,096\left(\mathrm{X}_{1}\right)-12,616\left(\mathrm{X}_{2}\right)$. Selanjutnya dapat dilihat ringkasan model regresi yang menunjukan nilai kkorelasi berdasarkan pada uji regresi linier sederhana.

Tabel 2

Model Summary

\begin{tabular}{|l|r|r|r|r|}
\hline Model & R & \multicolumn{1}{|c|}{ R Square } & Adjusted R Square & Std. Error of the Estimate \\
\hline 1 &, $962^{\mathrm{a}}$ &, 926 & &, 852 \\
\hline
\end{tabular}

Sumber: olahan data

Tabel 2 didapatkan nilai R Square sebesar 0,926 atau sebesar 92,6\%. Nilai tersebut memiliki arti bahwa 92,6\% profitabilitas perusahaan dapat dijelaskan oleh variabel Struktur modal dan Likuiditas perusahaan. Ini berarti pengaruh variabel independent terhadap variabel terikat sangat besar, sedangkan sisanya sebesar 7,4\% dipengaruhi oleh variabel lain selain dari Struktur Modal dan Likuiditas. 
Ermaini et al., Pengaruh Struktur Modal dan Likuiditas Terhadap Profitabilitas Perusahaan Otomotif di Indonesia pada PT Astra Internasional Tbk

\section{Simpulan}

Berdasarkan pada hasil dan pembahasan penelitian, dapat disimpulkan bahwa kinerja keuangan PT. Astra Internasional Tbk periode 2016 sampai dengan 2019 memiliki tren yang posistif, sedangkan pada tahun 2020 kinerja keuangan menurun dikarenakan adanya wabah pandemi covid 19. Selanjutnya rasio struktur modal dan likuiditas memiliki pengaruh positif dengan tingkat signifikannya yaitu sebesar $<5 \%$.

\section{Daftar Pustaka}

Daniel, P. 2020. Pengaruh Upah Dan Pendidikan Terhadap Produktivitas Tenaga Kerja Di Provinsi Jambi. Journal Development, 8(2), 96-102.

Wiarta, I. 2020. Pengaruh Rasio Kecukupan Modal, Likuiditas Dan Operasioal Terhadap Kinerja Keuangan Bank Syariah Di Indonesia (Studi Empiris Pada Bri Syariah). Journal Development, 8(1), 90-95. 